\title{
Finite element analysis of cast-in-situ RC frame corner joints under quasi- static and cyclic loading
}

\author{
István Haris (Corresponding Author) \\ Budapest University of Technology and Economics, Department of Structural Engineering \\ 3-9. Muegyetem rkp., Kmf. 85, Budapest, H-1111 (Hungary) \\ haris.istvan@epito.bme.hu
}

Zsolt Roszevák (Main Author)

Budapest University of Technology and Economics, Department of Structural Engineering

3-9. Muegyetem rkp., Kmf. 85, Budapest, H-1111 (Hungary)

roszevak.zsolt@epito.bme.hu

Manuscript Code: 1519

Date of Acceptance/Reception: 22.11.2019/20.06.2019

DOI: 10.7764/RDLC.18.3.579

\begin{abstract}
Many types of computer software are currently available for the numerical modeling of monolithic RC structures; however, the accuracy of the numerical models created with the programs can only be acceptable by using a well-developed modeling method. We present the behavior of monolithic RC frame corners and beam to column joints for quasi-static and cyclic lateral loads, using numerical models created by our modeling method. Several laboratory experiments have already been carried out to investigate the failure of the joints and the behavior of these unique connections. In this paper, we made three-dimensional nonlinear FE body models with different reinforcement shapes, based on actual laboratory tests. We present the behavior of the joints in case of monotonic increasing quasi-static and cyclic changing loads. The results of laboratory experiments found in the literature and finite element calculations are compared and the conclusions that can be drawn from them are summarized within this article.
\end{abstract}

Keywords: frame corner, beam-column joints, nonlinear finite element analysis, ATENA 3D software, monotonic increasing load, cyclic lateral load.

Introduction

Nowadays, research engineers are conducting numerical tests in a number of topics to analyze the behavior of individual structural elements by computer. At the same time, there is a growing demand from practicing engineers. However, in order to verify the numerical models and their results, it is essential to perform laboratory experiments to support the precision and accuracy of our numerical tests. From a practical point of view, it is important that the created numerical models follow the real behavior of the structure as much as possible. Therefore, our models are becoming more and more detailed and thus more complex. The properties of materials and material models can be used in the finite element software are not negligible for modeling of a cart-in-situ RC structure. So, we need to use software that can properly analyze the problem. The primary purpose of this article is to create various reinforced concrete frameworks (two perpendicular beams connecting to one node) and different column-beam joints (three perpendicular beams connecting to one node) using the modeling method we have developed. We examine the behavior of numerical models and compare the numerical results obtained with existing and available laboratory tests. The numerical experiments were carried out with the ATENA 3D software, which offers many possibilities for modeling monotonic increasing quasistatic and also cyclic loads. Thus, within the framework of this article, we present the individual modeling techniques, their advantages, disadvantages and possible errors.

State of the Art

\section{Historical review}

Monolithic RC frameworks are made in many domestic and international engineering practices. Since the middle of the $20^{\text {th }}$ century, many research works have been carried out and published on cast-in-situ reinforced concrete frameworks and on the design of certain joints in frames. There have been many laboratory experiments on the subject since the 1910s (Kazinczy, 1917) and due to the development of information technology, even numerical studies can be found in the literature. In this chapter we summarize the research trends and results of the monolithic RC frame corners and beam-column connections found in the literature.

In the Hungarian context, the first laboratory experiments were made in the 1910s regarding the design of cast-in-situ RC frames, including the corner joints of monolithic reinforced concrete basins (Kazinczy, 1917). During the series of 
experiments, the effect of the reinforcement used in the corner joint and the effect of the different reinforcement designs was examined in terms of the load-bearing capacity. Investigations of the various reinforcement designs and their impact on the load-bearing capacity of the intermediate " + " shaped and the external " $\mathrm{T}$ " shaped beam-column connections of reinforced concrete buildings were the basis for several subsequent research programs (Kordina \& Kohler, 1971). Many laboratory experiments have been conducted to investigate, among other things, the " $T$ " shaped beam-column connections, in which the actual load-bearing capacity of each specimen as well as the cross-sectional moment-drift curve have been defined according to the designed reinforcement placing (Kordina, 1978). On the basis of all these, several practical recommendations have been made for each reinforcement placing, such as the required anchoring length of the reinforcement bars at the joint. Based on previous laboratory test results, Kordina, Teutsch \& Wegener (1995) formulated a number of suggestions for the reinforcement of the joints of individual cast-in-situ RC components, which are applied by practicing engineers (Kordina, Teutsch \& Wegener, 1995). The effect of the various reinforcing designs of the closing and opening frame corners on the load-bearing capacity has been tested with several analytical models that have been verified by laboratory tests. Two-dimensional finite element tests on a rod model and on-way monotonic increasing laboratory tests have led to the conclusion that the relationship between the concrete and the reinforcement bar basically determines the applicability of the finite element model. It has also been shown that bars with small deviations in numerical models have no adverse effect on the load bearing capacity (Morgan, 2000). There are several analytical models supported by laboratory experiments on opening frame corners, which can be used to determine that the load bearing capacity of the connection is greatly influenced by the way of conducting the reinforcement, the angle of the angled joint, the applied ratio of the bars and the ratio of the transverse bars in the same total reinforcement bar consumption (Campana, Ruiz \& Muttoni, 2013). Furthermore, the use of transverse bars can significantly increase the load bearing capacity and deformation ability of the joint. Numerous linear and nonlinear finite element and analytical calculations have been made to test the opening frame corners (Szczecina \& Winnicki, 2015; Himanshu \& Roshan, 2018, Windisch, 2018). Szczecina \& Winnicki (2015) studied the modeling possibilities of cast-in-situ RC frames with 2D finite element models and analytical Strut-and Tie models (Szczecina \& Winnicki, 2015). Based on their results, the appropriate force-displacement characteristics can be achieved in a much simpler way if we assume a plane deformation state during the analysis.

Also, a series of laboratory tests have been carried out since the 1960s and 1970s in order to learn about the resistance and behavior of the relationship against earthquakes. Already in 1977, an innovative, partially prestressed beam-column connection was investigated by Park and Thompson (Park \& Thompson, 1977). Park \& Koeng (1979) conducted laboratory experiments on joints with novel connections, in which the beam-column joint has one more horizontal bar positioned in the center of the beam cross section (Park, Keong, 1979). They carried out laboratory experiments to examine the load-bearing capacity and ductility of the connections. In 1980, Beckingsale investigated the shear strength of the frame joints and the forces/stresses that awakened in reinforcement bars for various reinforcement designs (Beckingsale, 1980). It was concluded that in the so-called poorly ironed frame corner connections where no transversal reinforcement is placed, shear failure is expected. Earthquake resistance, and most notably energy dissipating zones have a significant impact on the bars used in the column (Pessiki, Conley, Gergely \& White, 1990). Analytical models were designed to calculate the shear strength of an interior beam-column connection of an RC structure with which resistance to seismic effects was determined by the Strut-and-Tie model (Hwang \& Lee, 1999, Lowes, Mitra \& Altoontash, 2003). With the Strut-and-Tie model they defined, only the cover graph of the force-displacement curve can be specified. Most of the research that the researchers are conducting today deals with the potential for retrofitting on structures. Based on laboratory experiments on various damaged beam-column connections, tests were carried out by using external steel sheets, GFRP plates, and HPFRCC strengthening (Engindeniz, Kahn \& Zureick, 2005; ParraMontesinos, Peterfreund \& Chao, 2005). Numerical experiments were performed on prestressed RC beam-column connections to investigate the load-bearing capacity and ductility of the joints (Ashtiani, Dhakal \& Scott, 2018; Yan, Xiao, Lin \& Niu, 2018). Numerical tests on a similar topic were completed by Arjamadi \& Yousefi (2018) (Arjamadi \& Yousefi, 2018). Their model is three-dimensional, taking into account the cyclic properties of the concrete, but the slipping of the bars and the effect of the reinforcement placing, which significantly modifies the load-bearing capacity of the joints, cannot be modeled. In general, there are many research programs on the subject; a large number of laboratory experiments and their results are available. It should be noted, however, that even in the most recent publications, a large number of laboratory experiments (Rahman, Dirar, Jemaa, Theofanous \& Elshafie, 2018) have been published, which were only used in minor cases for the validation of numerical models (Arjamadi \& Yousefi, 2018). Most numerical models are exclusively 2D linear with even rarer nonlinear, and even rarer three-dimensional nonlinear finite element calculations (Shahriar \& Hunar, 2019, Hawileh et al., 2010).

With this in mind, there is a growing demand for the development and application of three-dimensional nonlinear finite element models. Monolithic RC structures, such as the high-level numerical examinations of the joints discussed in this paper, are far from being fully exploited. Thus, based on real laboratory experiments, a validated 3D nonlinear finite 
element software can be used to investigate a number of structures, which have not yet been tested in laboratory conditions.

\section{Numerical study}

Methodology

The finite element models were built with the ATENA 3D nonlinear finite element software. In numerical studies, we first analyzed, up to failure, the behavior of frame corner and beam-column connections under quasi-static on-way monotonic increasing loading. Then we modeled the behavior of each of the beam-column joints under horizontal cyclic loads. The accuracy of numerical results was compared to the results of laboratory experiments, thus showing the accuracy and precision of the modeling method we have developed. The constructed numerical models were prepared in the same way as the laboratory experiments found in the literature (Sin \& Bing 2011; Morgan 2000; Masi, Santeriero \& Nigro 2013). The geometric dimensions and reinforcement of the numerical models were defined also in the same way as the specimens tested in the laboratory. The basic data of the laboratory test that form the basis of numerical analyses and the actual formation of the connections are summarized in Table 1. Diagrams of the static frames of the test specimens (NS, LS, RV, NE RB, Z2 RB, Z4 RB) tested in the laboratory are shown in Figure 1.

\begin{tabular}{|c|c|c|c|c|c|c|c|}
\hline \multicolumn{8}{|c|}{ Monotonic increasing quasi-static load } \\
\hline \multirow[b]{2}{*}{$\begin{array}{l}\text { Geometry of } \\
\text { specimen }\end{array}$} & \multirow[b]{2}{*}{$\begin{array}{c}\text { Reinfocemen } \\
\text { ttype }\end{array}$} & \multicolumn{4}{|c|}{ Applied reinfocement } & \multirow[b]{2}{*}{ Specimen } & \multirow[b]{2}{*}{$\begin{array}{l}\text { Laboratory test } \\
\text { performed by }\end{array}$} \\
\hline & & $\begin{array}{c}\text { Longitudinal } \\
\text { reincorcement } \\
\text { in the beam } \\
\end{array}$ & $\begin{array}{l}\text { Longitudinal } \\
\text { reincorcement } \\
\text { in the column }\end{array}$ & $\begin{array}{c}\text { Stirups in } \\
\text { the beam }\end{array}$ & $\begin{array}{l}\text { Stirrups in } \\
\text { the column }\end{array}$ & & \\
\hline & \multirow{6}{*}{ 登 } & $2+3 \varnothing 25$ & $8 \varnothing 20$ & $\varnothing 10 / 100$ & $\varnothing 10 / 300$ & NS01 & \multirow{6}{*}{$\begin{array}{l}\text { Sim Lim Yap, } \\
\text { Bing Li (2011) }\end{array}$} \\
\hline & & $2+3 \varnothing 25$ & $8 \varnothing 20$ & $\varnothing 10 / 80$ & $\varnothing 10 / 300$ & $\mathrm{NS} 02$ & \\
\hline & & $2+3 \varnothing 25$ & $8 \varnothing 20$ & $\varnothing 10 / 50$ & $\varnothing 10 / 300$ & $\mathrm{NS} 03$ & \\
\hline & & $3+3 \varnothing 25$ & $8 \varnothing 20$ & $2 \varnothing 10 / 100$ & $2 \varnothing 10 / 100$ & LS01 & \\
\hline & & $3+3 \varnothing 25$ & $8 \varnothing 20$ & $2 \varnothing 10 / 80$ & $2 \varnothing 10 / 80$ & LSO2 & \\
\hline & & $3+3 \varnothing 25$ & $8 \varnothing 20$ & $2 \varnothing 10 / 50$ & $2 \varnothing 10 / 50$ & LS03 & \\
\hline & & $8 \varnothing 16$ & $8 \varnothing 16$ & - & - & RV1 & \multirow{4}{*}{$\begin{array}{c}\text { Morgan } \\
\text { Johanson (2000) }\end{array}$} \\
\hline & & $5 \varnothing 16$ & $5 \varnothing 16$ & - & - & RV9 & \\
\hline & & $6 \varnothing 16$ & $6 \varnothing 16$ & - & - & RV2 & \\
\hline & & $5 \varnothing 16$ & $5 \varnothing 16$ & - & - & RV10 & \\
\hline \multicolumn{8}{|c|}{ Cyclic loading } \\
\hline \multirow[b]{2}{*}{$\begin{array}{l}\text { Geometry of } \\
\text { specimen }\end{array}$} & \multirow[b]{2}{*}{$\begin{array}{c}\text { Reinfocemen } \\
\text { ttype }\end{array}$} & \multicolumn{4}{|c|}{ Applied reinfocement } & \multirow[b]{2}{*}{ Specimen } & \multirow[b]{2}{*}{$\begin{array}{l}\text { Laboratory test } \\
\text { performed by }\end{array}$} \\
\hline & & $\begin{array}{c}\text { Longitudinal } \\
\text { reincorcement } \\
\text { in the beam } \\
\end{array}$ & $\begin{array}{l}\text { Longitudinal } \\
\text { reincorcement } \\
\text { in the column }\end{array}$ & $\begin{array}{c}\text { Stirups in } \\
\text { the beam }\end{array}$ & $\begin{array}{l}\text { Stirups in } \\
\text { the column }\end{array}$ & & \\
\hline & \multirow{3}{*}{ 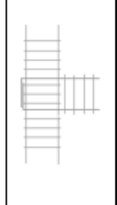 } & $2+2 \varnothing 12$ & $4 \varnothing 14$ & $\varnothing 8 / 250$ & $\varnothing 8 / 200$ & NE RB & \multirow{3}{*}{$\begin{array}{l}\text { Angelo Masi, } \\
\text { Giuseppe } \\
\text { Santariero, } \\
\text { Domenico Nigro } \\
\text { (2013) }\end{array}$} \\
\hline & & $\begin{array}{c}2+2 \varnothing 14+ \\
2+2 \varnothing 12\end{array}$ & $6 \varnothing 14$ & $\begin{array}{c}\varnothing 8 / 100 / \\
250\end{array}$ & $\begin{array}{l}\varnothing 8 / 75 / \\
200\end{array}$ & $\mathrm{Z} 4 \mathrm{RB}$ & \\
\hline & & $\begin{array}{c}3+2 \varnothing 16+ \\
1 \varnothing 12\end{array}$ & $6 \varnothing 14$ & $\begin{array}{c}\varnothing 8 / 100 / \\
250\end{array}$ & $\begin{array}{l}\varnothing 8 / 75 / \\
200\end{array}$ & $\mathrm{Z} 2 \mathrm{RB}$ & \\
\hline
\end{tabular}

Figure 1. Static frame of the specimens. (a) NS and LS specimens, (b) RV1/RV2 specimens, (c) RV9/RV10 specimens, (d) NE/Z2/Z4 RB specimens. Source: Self-Elaboration

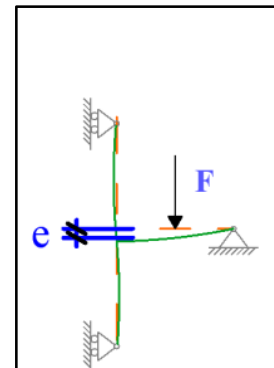

(a)

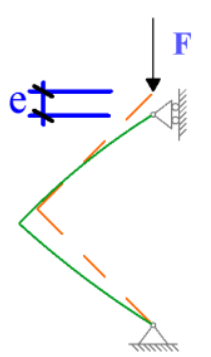

(b)

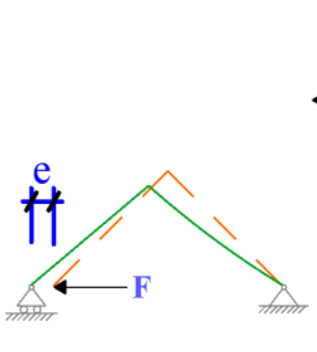

(c)

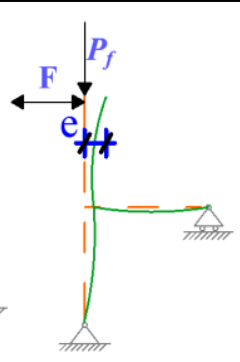

(d) 


\section{Quasi-static analyses}

In the quasi-static numerical experiments, the material model of concrete was defined with an individually parametrized model on the basis of our previous results (Haris \& Roszevák, 2017). The concrete material model includes the following effects of concrete behavior (Cervenka et al., 2014): non-linear behaviour in compression including hardening and softening, reduction of compressive strength after cracking (Van Mier, 1986), fracture of concrete in tension based on the nonlinear fracture mechanics (Hordijk, 1991), biaxial strength failure criterion (Kupfer et al.,1969), tension stiffening effect, reduction of the shear stiffness after cracking (Kolmar, 1986) and the fixed (Cervenka, 1985, Darwin \& Pecknold, 1974) and rotated (Vecchio \& Collins, 1986, Crisfield \& Wills, 1989) crack direction. The reinforcement material model is specified according to the properties of the reinforcement used in the laboratory experiments and the real stressdeformation characteristics are provided. For the specimens "NS" and "LS", a linear elastic-linear hardening material model was used because the results of the tensile test used in the laboratory test were not available. The strength properties of the concrete and reinforcement bars were defined according to the laboratory tests. The relationship between concrete and reinforcement bars was calculated and defined based on the CEB-FIP MODEL CODE 1990 (CEB, 1993). The longitudinal bars were modeled with their real geometry and diameter, the stirrups with a closed rectangular shape other than the actual bending shape, but with their real diameter. The numerical models corresponding to the quasi-static load of the specimens' (RV) frame and beam-column joints (NS and LS) were built up with several different reinforcements in the vicinity of the connection (see Figure 2 ).

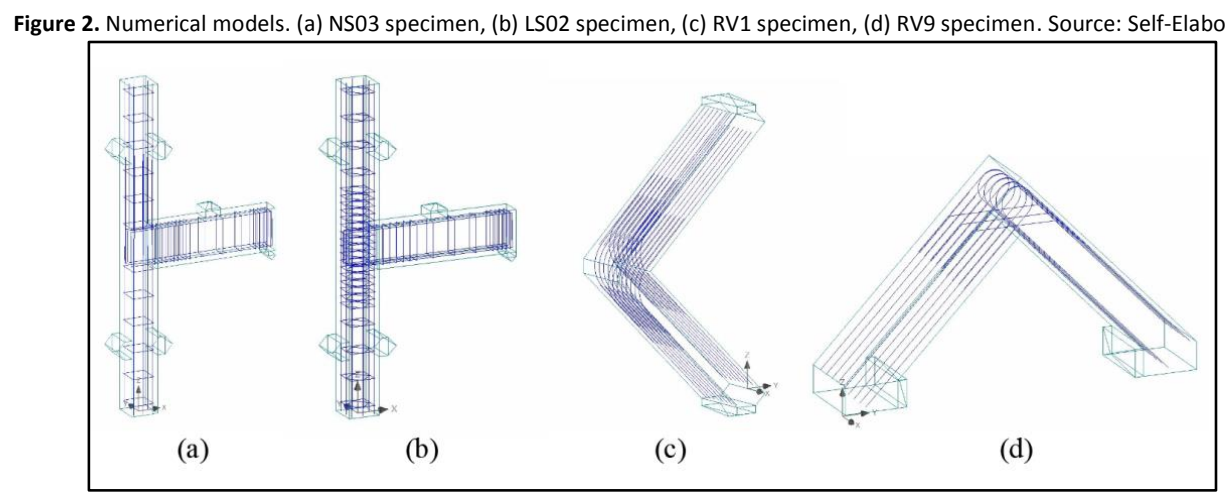

\section{Cyclic analyses}

In our cyclic test, the material for concrete shown in Figure 3(a) was used. For tensile (fracture) and compressive (plastic) behavior, the software applied a smeared crack approach in respect of the concrete junction using a fracture plastic model.

Figure 3. Material properties. (a) concrete material model, (b) cyclic reinforcement model, (c) bond-slip relationship. Source: Cervenka et al. (2014).

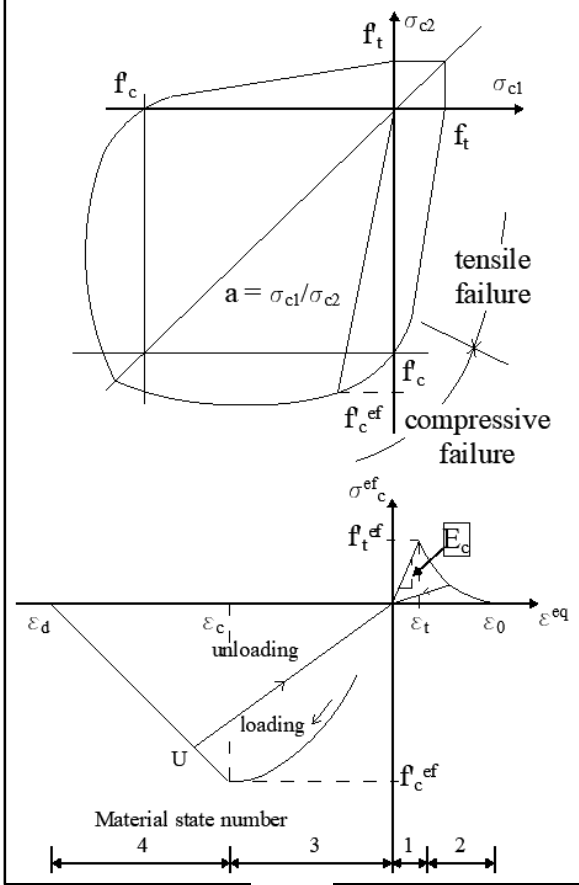

(a)
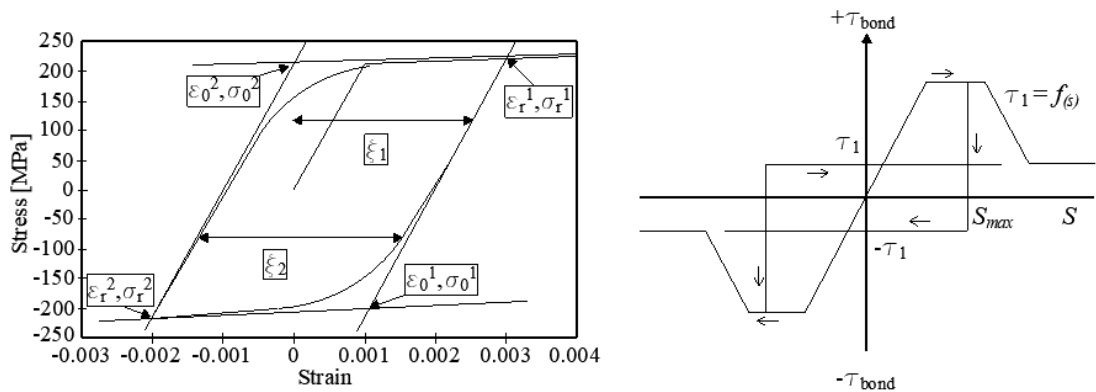

(b) 
The fracture model is based on the classical orthotropic smeared crack band and crack formulation model (Cervenka, 1985, Darwin \& Pecknold, 1974). Rotating and fixed crack models can be used in relation to exponential softening and Rankine tensile failure criterion. Plasticity for concrete in compression is inspected by the Menetery-Williams failure surface (Cervenka et al., 2014). The failure surface in compression is expressed in terms of three (independent) stress invariants such as hydrostatic stress, deviatoric stress and deviatoric polar angle. ATENA adds a so-called Unloading Factor to model concrete behavior under cyclic loading. The Unloading Factor controls crack closure stiffness. The factor mainly influences the shape of the hysteresis curve; in our analyses, the parameter was set to zero because this value provides the best fit to real behavior. The compressive strength of the concrete is defined in the same way as in the laboratory tests $\left(f_{c}^{\prime}=21,5 \mathrm{MPa}\right)$. The reinforcement is defined by the cyclic properties based on the Menegotto-Pinto model (Menegotto \& Pinto, 1973) (see Figure 3(b)). The yield strength and tensile strength of the reinforcement bars are also the same as in the laboratory experiments $\left(f_{y}=480 \mathrm{MPa}, f_{u}=540 \mathrm{MPa}\right)$. In the longitudinal bars placed in the beam, the effect of slipping is taken into account. However, the perfect connection for the stirrups and the bars is set in the beam. In cases where the slip of the reinforcement bars is taken into account, the relationship between the concrete and the reinforcement bars is defined by a memory bond parametrized model. For the bond-slip relationship (see Figure $3(\mathrm{c}))$, the model is taken according to the CEB-FIP Model Code $1990\left(\tau_{\max }=5.38 \mathrm{MPa}, \tau_{f}=0.8 \mathrm{MPa}, s_{1}=s_{2}=\right.$ $0.6 \mathrm{~mm}, s_{3}=2.5 \mathrm{~mm}$ ). The placing of the bars is defined in the same way as in quasi-static tests. Figure 4(a) shows the direction of the positive and negative load as well as the measured force (F) and the measured displacement (e). In the laboratory test, the constant vertical force $\left(P_{f}=270 \mathrm{kN}\right)$ at the top of the column was also defined for the finite element model (see Figure 4(a)). See Figure 4(b, c, d) for models with a horizontal cyclic load.

Figure 4. Static frame and numerical models. (a) direction of the load, (b) NE RB specimen, (c) Z2 RB specimen, (d) Z4 RB specimen. Source: Self-Elaboration.

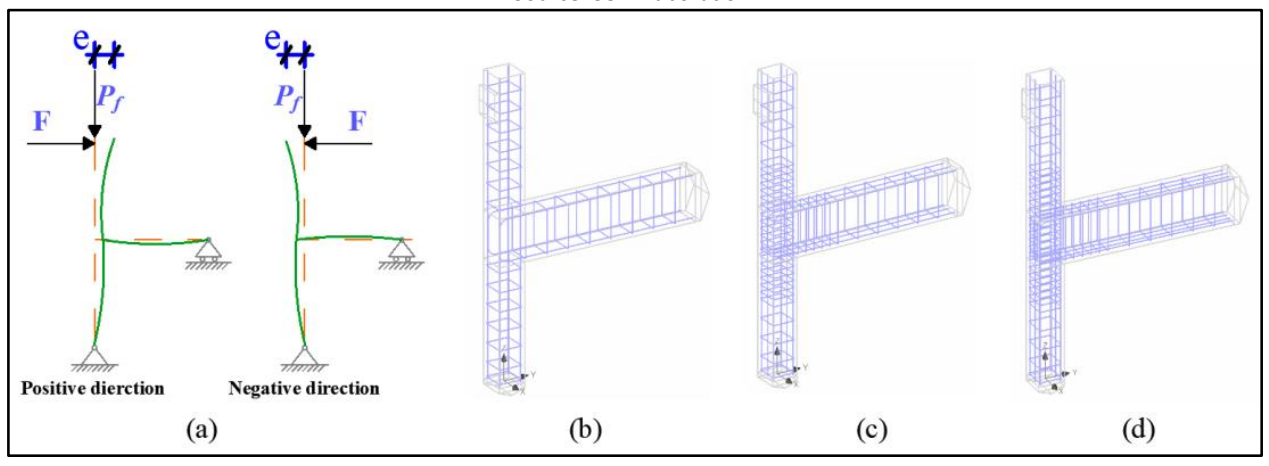

\section{Numerical properties}

For all nonlinear analyses, an iterative method (Newton-Raphson iteration method) was used to perform the iteration process. The Cholesky resolution was used to solve the state equation of the structure. In numerical models we used uniformly quadratic bar functions, and we used 20-node brick (In case of NE RB, Z2 RB and Z4 RB specimens) and 10node tetra (in case of RV specimens) elements for the concrete (Haris \& Roszevák, 2017). The finite element mesh is distributed uniformly so that there are at least 4 finite elements within the given cross-sectional dimension (Haris \& Roszevák, 2017). This means in our models the size of the finite element mesh surrounding the joint is not bigger than $4-5 \mathrm{~cm}$. The basic mesh size of the other part of the model was $10-15 \mathrm{~cm}$.

\section{Load history}

The laboratory experiments performed (Masi, Santeriero \& Nigro, 2013) were carried out in a displacement-controlled manner, which is characterized by the load history shown in Figure 5 below. In order to investigate finite element calculations for a suitable offset, the magnitude of relative drift ratio in international standards is reviewed, see Table 2(a).

Figure 5. Load history. Source: Masi, Santeriero \& Nigro (2013).

Load history

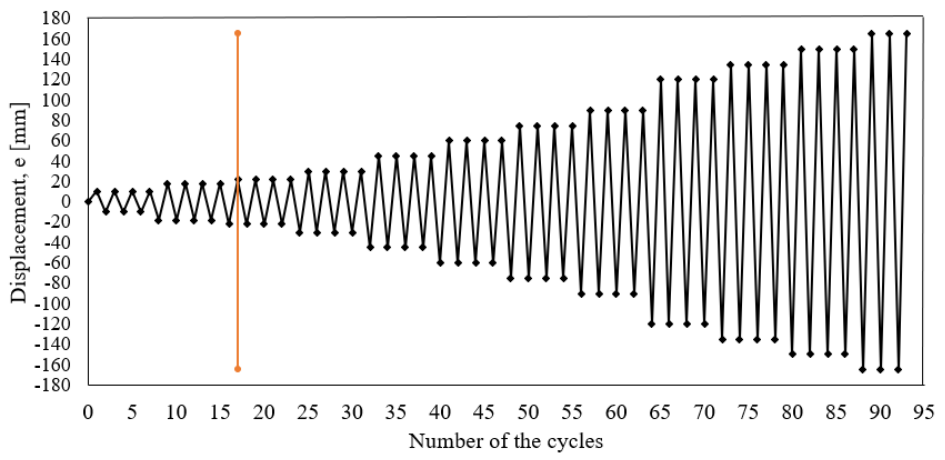


Table 2. Drift ratios and numerical results. (a) Drift ratios in standards, (b) Numerical results. Source: Self-Elaboration.

\begin{tabular}{|c|c|c|c|c|c|c|}
\hline \multicolumn{3}{|c|}{ (a) Drift ratios } & \multicolumn{4}{|c|}{ (b) Numerical results } \\
\hline $\begin{array}{c}\text { Name of the } \\
\text { standards }\end{array}$ & Country & $\begin{array}{c}\text { Drift ratio } \\
{[\%]}\end{array}$ & Specimens & $\begin{array}{l}\text { Force of failure } \\
{[\mathrm{kN}]}\end{array}$ & $\begin{array}{c}\text { Displacement } \\
{[\mathrm{mm}]}\end{array}$ & $\begin{array}{c}\text { Drift ratio } \\
{[\%]}\end{array}$ \\
\hline NRCC. 2005. & Canada & 2.5 & NE RB & 21.41 & 24.1 & 0.75 \\
\hline NZS 1170.5:2004 & $\begin{array}{c}\text { New } \\
\text { Zealand }\end{array}$ & $1.5-2.0$ & $\mathrm{Z2} \mathrm{RB}$ & 40.12 & 33.55 & 1.05 \\
\hline AS1170.4 2007 & Australia & 1.5 & Z4 RB & 39.73 & 32.59 & 1.02 \\
\hline IBC-2009 & USA & 1.5 & & & & \\
\hline
\end{tabular}

In the laboratory tests, the maximum horizontal displacement value was about $160 \mathrm{~mm}$, which corresponds to a $5 \%$ drift ratio, which is higher than the limits of the domestic and international standards (1.5 to $2.5 \%$ ). The individual steps were defined in the numerical model in the same number and extent as in the laboratory tests. In the light of the above, finite element calculations were performed up to the third load level. Numerical testing was performed in the same way as the laboratory experiments (displacement-controlled).

Prior to performing the cyclic tests, one-way monotonic increasing quasi-static tests were performed on the specimens tested in this article, which were performed as described in the quasi-static studies section. The purpose of the study was to determine the load bearing capacity and deformability of the specimens by numerical calculations, and we wished to compare the value of the maximum displacement under the load used (in terms of load history) in the analyses carried out in the laboratory experiments with the results of the numerical tests. The numerical results obtained with one-way (positive direction) monotonic increasing quasi-static load are shown in Figure 6 . The characteristic values for the specimens are summarized in Table 2(b).

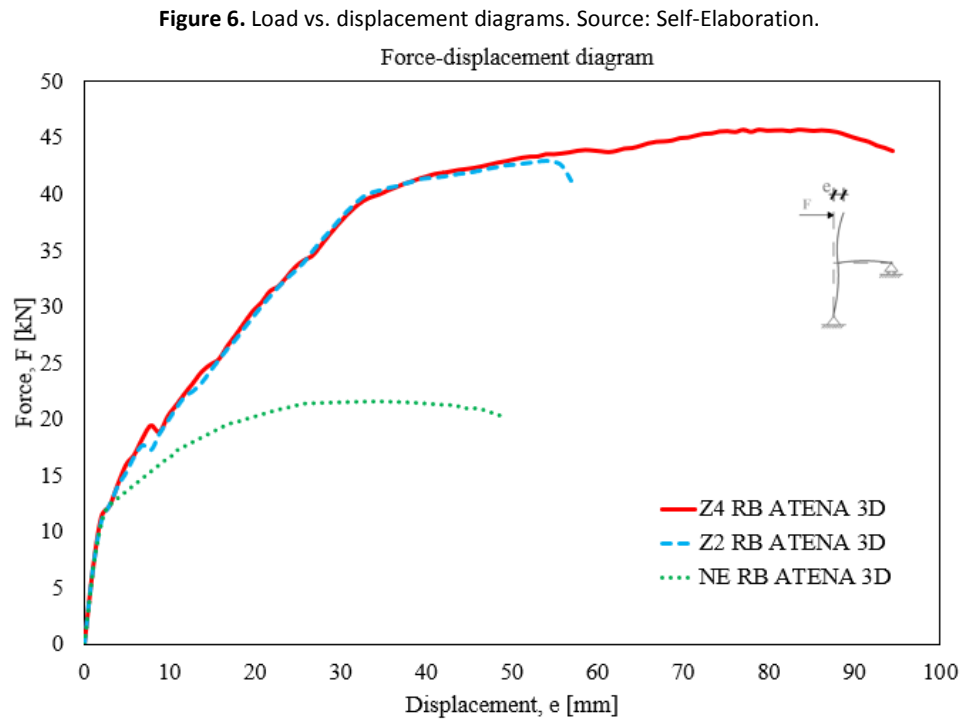

Within the scope of this article, studies were based on the load bearing capacities and displacements associated with the failure specified in the quasi-static experiment. Taking into account the drift ratio in international standards, finite element calculations were performed by setting a limit, which represents a drift ratio of $1 \%$.

Results and discussion

\section{Numerical results based on quasi-static analyses}

In this chapter we present in detail the results of numerical examinations. First, the results of the studies of the beamcolumn joints are described. Calculations were also carried out with force and displacement control. The graph below shows the force and displacement diagrams of the "NS" specimens (Figure 7(a), (b)). In the figures it can be observed that the two models yield almost the same results on the initial, uncracked part. However, in the state of failure, the displacement-controlled model does not describe the so-called descending plastic deformation section. The results of the numerically derived models with different controls are summarized in the table below (Table 3(a)). 
Figure 6. Load-displacement diagrams. Source: Self-Elaboration.
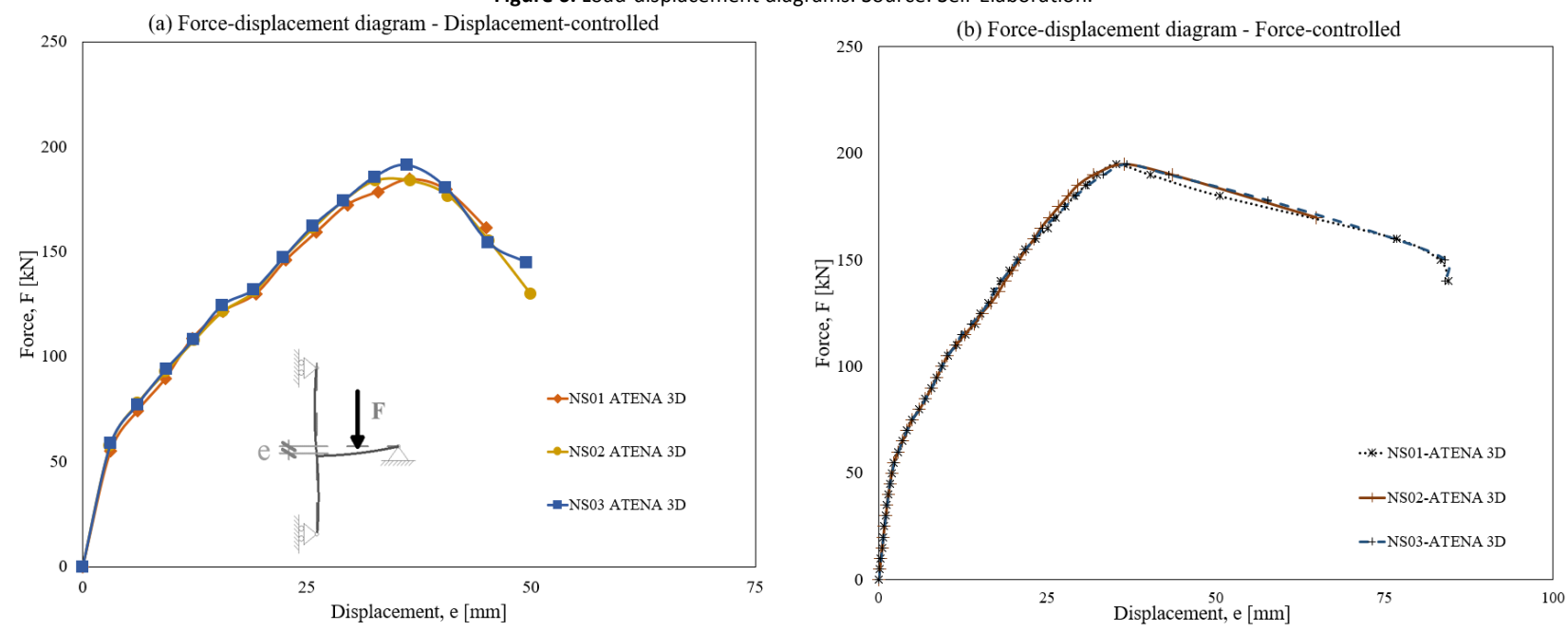

(d) Force-displacement diagram
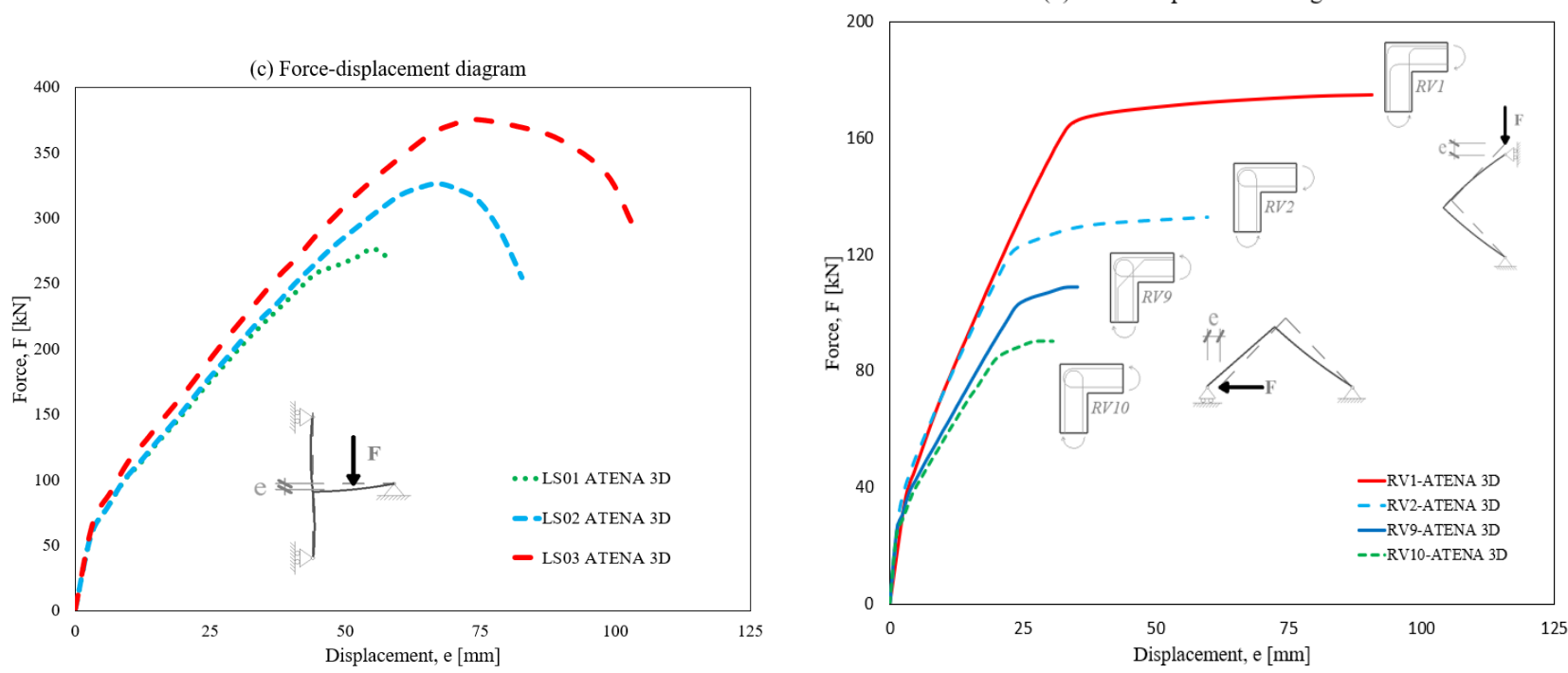

In the initial phase, which corresponds to elastic stress state I (difference: 0.85 to $2.73 \%$ ), and in the state near to failure, each variant shows a very good match (difference in force at failure: 1.98 to $5.49 \%$, deviation from deflection: 1.79 to 8.69\%). There is no significant difference between the results of the numerical models with different reinforcements (the highest difference is $+5.49 \%$, the smallest difference is $-8.69 \%$ ). The difference can be seen in the decay after failure, which becomes important later in the cyclic friction modeling of cyclic loading.

The results of the experiments on "LS" specimens are shown in Figure 7(c). In this case, force-controlled experiments were performed. The results of the numerical studies are summarized in Table 3(b). On the graph it can be observed that the results of the models with different stirrup distances show a relatively large variation in the load-bearing capacity (deviation: 15 to $26 \%$ ), even though in the models the "classic" curved iron quantity is the same. In the case of specimen "LSO1", the descending plastic deformation phase is not observed, but there is some plasticity already in specimens "LSO2" and "LSO3". The deformability of the test specimens "LSO2" and "LSO3" is greater (difference: 17 to 26\%), so they behave more ductically. The failure of specimen "LSO1" can be considered a "brittle" failure. In all cases, the drawn reinforcement ratio of the test specimens is the same as that of the placing, together with the density of the stirrups, which increases the load-bearing capacity (load-bearing capacity increase: 15 to $26 \%$ ).

A so-called closing frame was investigated for specimens "RV1" and "RV2", and the opening frame corner for specimens "RV9" and "RV10". The resulting force-displacement diagrams are shown in Figure 6(d). For specimens "RV1" and "RV2", the reinforcement ratio is the same, but the reinforcement placing is different. In the two models (RV1, RV2), the magnitude of the cracking force is nearly the same (cracking force: "RV1": $39.16 \mathrm{kN}$, "RV2": $37.40 \mathrm{kN}$ ). The force at the failure for specimen "RV1' is approximately $165.54 \mathrm{kN}$ and $122.40 \mathrm{kN}$ for specimen "RV2". When testing the opening frame corners, the curved reinforcement ratio used for test pieces "RV9" and "RV10" is the same, but the placing of the curved bars is different. A change in the "efficiency" of the used reinforcement bars can be demonstrated in this case. The force-displacement diagrams are the same in nature; however, due to the biased reinforcement, specimen "RV9" 
is able to absorb more force (force at failure: "RV9": $1202.00 \mathrm{kN}$, "RV10": $85.00 \mathrm{kN}$ ). The results of each of the numerical analyses are summarized in Table 3(c).

Table 3. Numerical results. Source: Self -Elaboration, Sin \& Bing (2011), Morgan (2000).

\begin{tabular}{|c|c|c|c|c|c|c|c|c|c|}
\hline \multirow[b]{3}{*}{ Specimen } & \multicolumn{8}{|c|}{ (a) Numerical results (NS specimens) } & \multirow[b]{3}{*}{$\begin{array}{l}\text { Differe } \\
\text { nce [\%] }\end{array}$} \\
\hline & \multicolumn{2}{|c|}{ Cracking force $[\mathrm{kN}]$} & \multirow[b]{2}{*}{$\begin{array}{c}\text { Differenc } \\
\text { e [\%] }\end{array}$} & \multicolumn{2}{|c|}{ Force of failure $[\mathrm{kN}]$} & \multirow[b]{2}{*}{$\begin{array}{c}\text { Differenc } \\
\text { e [\%] }\end{array}$} & \multicolumn{2}{|c|}{ Displacement [mm] } & \\
\hline & $\begin{array}{c}\text { Displacement- } \\
\text { controlled }\end{array}$ & $\begin{array}{c}\text { Force- } \\
\text { controlled }\end{array}$ & & $\begin{array}{c}\text { Displacement- } \\
\text { controlled }\end{array}$ & $\begin{array}{c}\text { Force- } \\
\text { controlled }\end{array}$ & & $\begin{array}{c}\text { Displacement- } \\
\text { controlled }\end{array}$ & $\begin{array}{c}\text { Force- } \\
\text { controlled }\end{array}$ & \\
\hline NS01 & 49.35 & 48.00 & -2.73 & 183.81 & 193.00 & +4.99 & 36.58 & 33.40 & -8.69 \\
\hline NSO2 & 53.45 & 54.00 & +0.85 & 183.81 & 194.50 & +5.49 & 36.58 & 33.50 & -8.42 \\
\hline NSO3 & 58.63 & 57.50 & -1.93 & 191.18 & 195.00 & +1.98 & 36.14 & 36.80 & +1.79 \\
\hline
\end{tabular}

(b) Numerical results (LS specimens)

\begin{tabular}{cccc}
\hline Specimen & $\begin{array}{c}\text { Cracking force } \\
{[\mathrm{kN}]}\end{array}$ & $\begin{array}{c}\text { Force of failure } \\
{[\mathrm{kN}]}\end{array}$ & $\begin{array}{c}\text { Displacement } \\
{[\mathrm{mm}]}\end{array}$ \\
\hline LS01 & 57.87 & 276.50 & 55.20 \\
LS02 & 57.86 & 326.10 & 67.14 \\
LS03 & 66.53 & 375.01 & 73.85 \\
\hline
\end{tabular}

(c) Numerical results (RV specimens)

\begin{tabular}{cccc}
\hline Specimen & $\begin{array}{c}\text { Cracking force } \\
{[\mathrm{kN}]}\end{array}$ & $\begin{array}{c}\text { Force of failure } \\
{[\mathrm{kN}]}\end{array}$ & $\begin{array}{c}\text { Displacement } \\
{[\mathrm{mm}]}\end{array}$ \\
\hline RV1 & 39.16 & 165.54 & 34.52 \\
RV2 & 37.40 & 120.70 & 22.81 \\
RV9 & 27.20 & 102.00 & 23.59 \\
RV10 & 25.50 & 85.00 & 20.51 \\
\hline
\end{tabular}

\section{Numerical results based on cyclic analyses}

The results of the numerical experiments are described in detail below. The finite element calculation was feasible up to our limit. The modeling technique we used was not suitable for the examination of the deformations above the specified limit, and the calculations cannot be run at post-restriction load levels. The results obtained in the numerical experiment were proportionally determined on the basis of the laboratory experiments (Masi, Santeriero \& Nigro, 2013) for later comparability. The value of the resulting displacement was divided by the total height of the specimens $(\mathrm{H}=$ $3.20 \mathrm{~m}$ ) to yield the drift ratio. The force-drift diagram of the numerical tests on specimen "NE RB" is shown in Figure 7 (a). On the force rotation diagram, it can be observed that the drift values converted from the displacement are identical at the end of each cycle. At the end of the cycles of the first load level in the positive direction, the drift ratio is the same (drift ratio: $0.33 \%)$, but the value of the force shows a decreasing tendency $(10.14 \mathrm{kN} ; 10.10 \mathrm{kN} ; 9.92 \mathrm{kN}$; $9.78 \mathrm{kN}$ ). The numerical analysis stopped after the $9^{\text {th }}$ cycle: at the end of the cycle the specimen was destroyed (force at failure: $16.86 \mathrm{kN}$ ). The same drift values had different force values at the end of the subsequent cycles. The results were summarized in a tabular form, see Table 4.

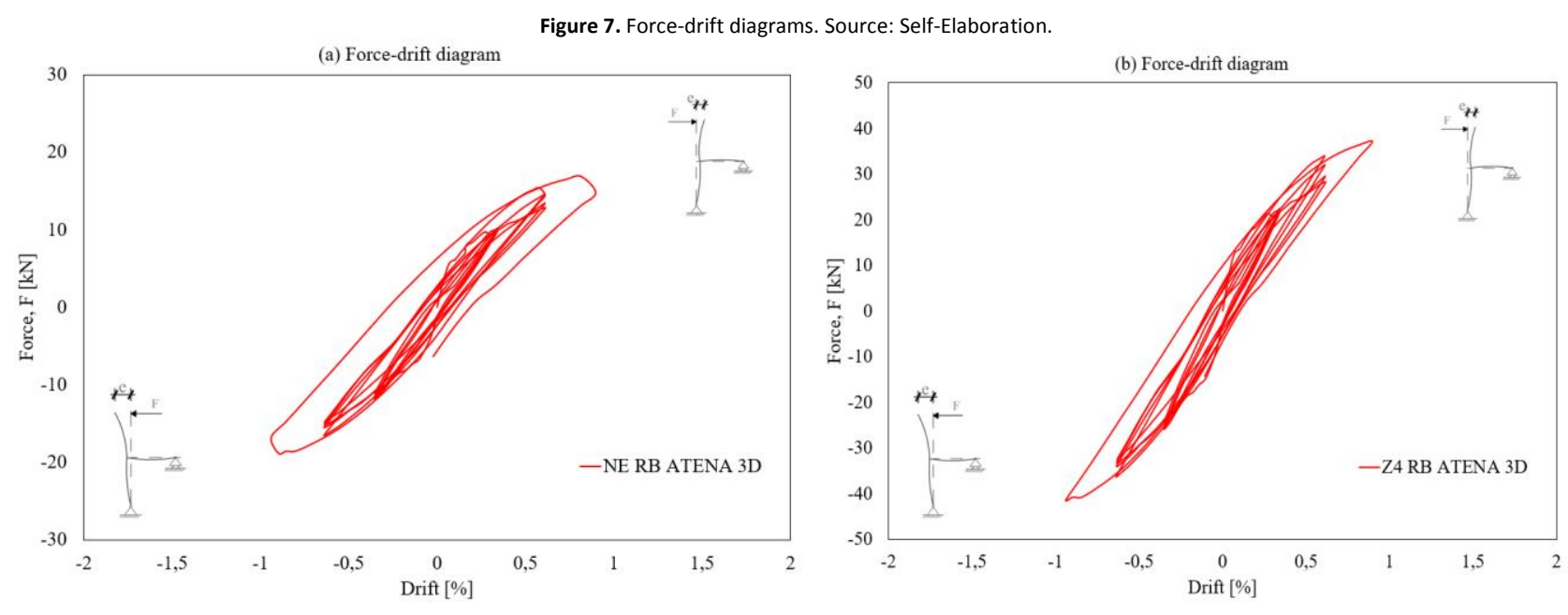




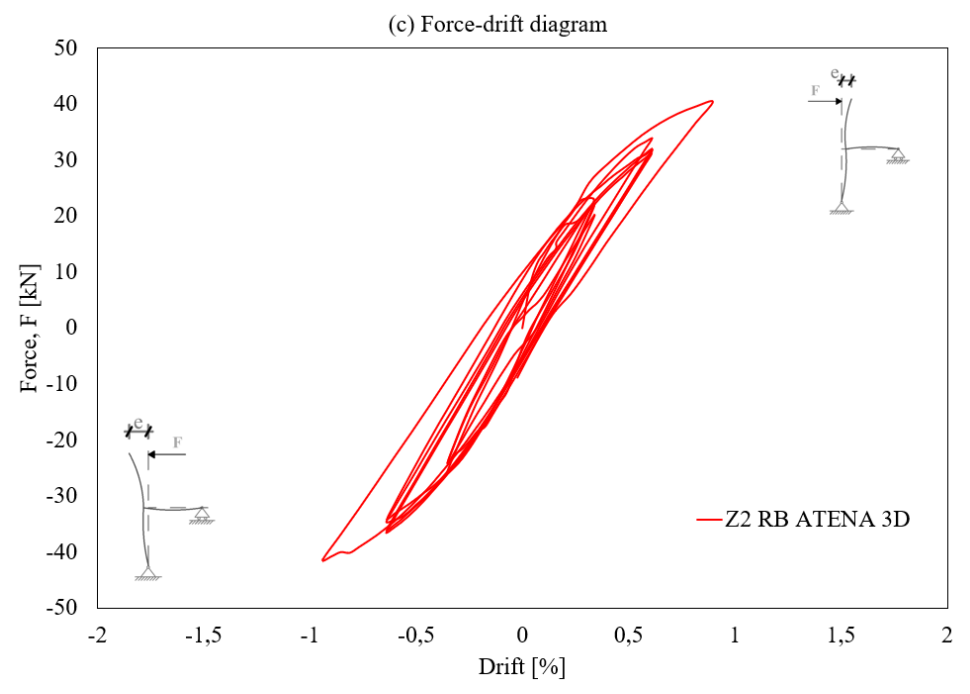

Table 4. Numerical results. Source: Self-Elaboration; Masi, Santeriero \& Nigro (2013).

\begin{tabular}{|c|c|c|c|c|c|c|c|c|c|}
\hline \multirow[b]{2}{*}{$\begin{array}{c}\text { Number of } \\
\text { cycles [-] }\end{array}$} & \multicolumn{3}{|c|}{ "NE RB" specimen } & \multicolumn{3}{|c|}{ "Z4 RB" specimen } & \multicolumn{3}{|c|}{ "Z2 RB" specimen } \\
\hline & Drift [\%] & $\begin{array}{c}\text { Force } \\
\text { value at } \\
\text { the end of } \\
\text { the cycle } \\
{[\mathrm{kN}]}\end{array}$ & $\begin{array}{l}\text { Difference } \\
\text { of force } \\
{[\%]}\end{array}$ & Drift [\%] & $\begin{array}{c}\text { Force } \\
\text { value at } \\
\text { the end of } \\
\text { the cycle } \\
{[\mathrm{kN}]}\end{array}$ & $\begin{array}{c}\text { Difference } \\
\text { of force } \\
{[\%]}\end{array}$ & Drift [\%] & $\begin{array}{c}\text { Force } \\
\text { value at } \\
\text { the end of } \\
\text { the cycle } \\
{[\mathrm{kN}]}\end{array}$ & $\begin{array}{c}\text { Difference } \\
\text { of force } \\
\text { [\%] }\end{array}$ \\
\hline 1 & +0.33 & 10.14 & - & +0.33 & 22.31 & - & +0.33 & 22.93 & - \\
\hline 2 & & 10.1 & -0.39 & & 22.23 & -0.35 & & 22.28 & -2.83 \\
\hline 3 & & 9.92 & -2.69 & & 21.84 & -2.11 & & 22.02 & -3.96 \\
\hline 4 & & 9.78 & -3.55 & & 21.59 & -3.22 & & 18.40 & -19.75 \\
\hline 1 & -0.33 & -11.75 & - & -0.33 & -25.85 & - & -0.33 & -25.87 & - \\
\hline 2 & & -11.55 & -1.70 & & -25.42 & -1.62 & & -24.15 & -6.65 \\
\hline 3 & & -11.11 & -5.44 & & -24.45 & -5.41 & & -24.08 & -6.92 \\
\hline 5 & +0.63 & 15.41 & - & +0.63 & 33.90 & - & +0.63 & 33.22 & - \\
\hline 6 & & 14.54 & -5.64 & & 31.97 & -5.69 & & 32.02 & -3.61 \\
\hline 7 & & 13.40 & -13.04 & & 29.49 & -13.00 & & 31.80 & -4.27 \\
\hline 8 & & 12.81 & -16.87 & & 28.18 & -16.85 & & 31.18 & -6.14 \\
\hline 4 & -0.63 & -16.49 & - & -0.63 & -36.28 & - & -0.63 & -36.51 & - \\
\hline 5 & & -15.48 & -6.12 & & -34.00 & -6.28 & & -36.11 & -1.09 \\
\hline 6 & & -15.07 & -8.61 & & -33.16 & -8.60 & & -34.64 & -5.12 \\
\hline 7 & & -14.82 & -10.13 & & -32.61 & -10.12 & & -34.09 & -6.63 \\
\hline 9 & +0.81 & 16.86 & - & +0.90 & 37.11 & - & +0.93 & 39.60 & - \\
\hline 8 & -0.81 & -18.80 & - & -0.90 & -41.36 & - & -0.93 & -40.76 & - \\
\hline
\end{tabular}

There is a similar phenomenon in test specimen "Z4 RB" as in specimen "NE RB". The length of the longitudinal reinforcement bars placed in the column and the beam of the specimen are larger than in the case of the "NE RB" specimen, and the spacing of the stirrups is denser. For specimen "Z4 RB" at the final cycle (cycle 9), the force at the failure is $37.11 \mathrm{kN}$ (see Figure $7(\mathrm{~b})$ ). In this case as well, the force exerted by the test specimen shows a similar tendency as in specimen "NE RB". The decrease in force value for the same drift value at the first load level after the first cycle is $-0.35 \%$ and after the fourth cycle is $-3.22 \%$. The results obtained in numerical analyses are summarized in Table 4 .

Numerical calculations were also performed for specimen "Z2 RB". The resulting force-drift diagram is shown in Figure 7(c). At the end of the test, the force at the end of each cycle is similar to the previous one. At the second load level, the deviation (negative load direction) of forces $(-3.61 \%,-4.27 \%$ and $-6.14 \%)$ corresponds to the same drift values. In this case, the numerical experiment was stopped after the $9^{\text {th }}$ cycle. The test was carried out in the direction of the positive load up to $39.60 \mathrm{kN}$. The results were also summarized in a tabular form, see Table 4. 


\section{Comparison of numerical and experimental results}

In this chapter we summarize and compare the numerical and laboratory experiment results obtained in the literature (Sin \& Bing, 2011, Morgan, 2000, Masi, Santeriero \& Nigro, 2013). First, the results of the experiments on specimens "NS" were compared (see Figure 8(a, b). The results of numerical examinations and laboratory experiments (Sin \& Bing, 2011, Morgan, 2000) are summarized in Table 5. Until failure, there is a good match between the laboratory and numerical experiment results; even after failure, the plastic deformation phase can be achieved with the applied model settings.

In the following, the results of the laboratory and numerical tests performed on specimens "LS" are also illustrated in force-displacement diagrams (see Figure 8(c)). The results obtained are summarized in a tabular form, see Table 5. In the case of test specimens "LS", the numerical results, in good correspondence with the results of the laboratory experiments, were almost the same until initial stress state I was reached. There is a difference of - 7.89\% for "LS01", $8.22 \%$ for "LSO2" and $-8.08 \%$ for "LSO3" in the cracking force. Following the cracking, the stiffness of the individual numerical models and the direction of the force-displacement diagram follow the laboratory experiments properly. This is also shown by the fact that the forces associated with the failure (in case of lab test "LS01": $276.30 \mathrm{kN}$, from the numerical test: $276.50 \mathrm{kN}$ ) are very good. In both laboratory and numerical experiments, it can be observed that due to the same tensile reinforcement ratio and the use of different reinforcement placing, the load-bearing capacity of the specimens is different. The force of failure for specimen "LS01" is $276.30 \mathrm{kN}$ (lab test) and $276.50 \mathrm{kN}$ (numerical experiment), for specimen "LS03" it is $371.70 \mathrm{kN}$ (lab test) and $375.10 \mathrm{kN}$ (numerical experiment). We present the results of numerical and experimental laboratory tests carried out on opening and closing frame corners. The forcedisplacement diagrams obtained from the experiments are shown in Figure 8(d), and the results are summarized in Table 5.

The numerical results of specimens "RV1" and "RV2" show a very good match in this case until the cross-sectional cracking occurs, and the laboratory results are well approximated by the numerical model. The value of the cracking force for specimen "RV1" is $40.00 \mathrm{kN}$ (lab test) and $39.10 \mathrm{kN}$ (numerical experiment). In this case, involving two specimens with different reinforcement placing, but with the same tensile reinforcement ratio, there is a significant difference between the load-bearing capacity in the numerical experiments ("RV1": 165.54 kN; "RV2": 122.40 kN), and also in the laboratory tests ("RV1": $165.00 \mathrm{kN}$; "RV2": $121.00 \mathrm{kN}$ ).

The test of the opening frame ("RV9" and "RV10") also shows a good match between the results of laboratory and numerical experiments. The force at cracking in the finite element model is almost the same as in the laboratory experiment (deviation: "RV9": 5.88\%; "RV10": 1.65\%). In this case, the failure occurs in the same way as in the laboratory experiment in the case of specimen "RV10" at lower force level (laboratory test: $87.00 \mathrm{kN}$, numerical experiment: 90.10 $\mathrm{kN})$. In the case of test specimen "RV9", the tensile reinforcement ratio is the same as for test specimen "RV10", but the placing of the bars is different. For specimen "RV9", with the same reinforcement ratio (as "RV10"), the force at failure in the laboratory test is $109.00 \mathrm{kN}$, and $108.80 \mathrm{kN}$ the numerical test.

Figure 8. Comparison of numerical and experimental results. Source: Self-Elaboration; Sin \& Bing (2011); Morgan (2000)
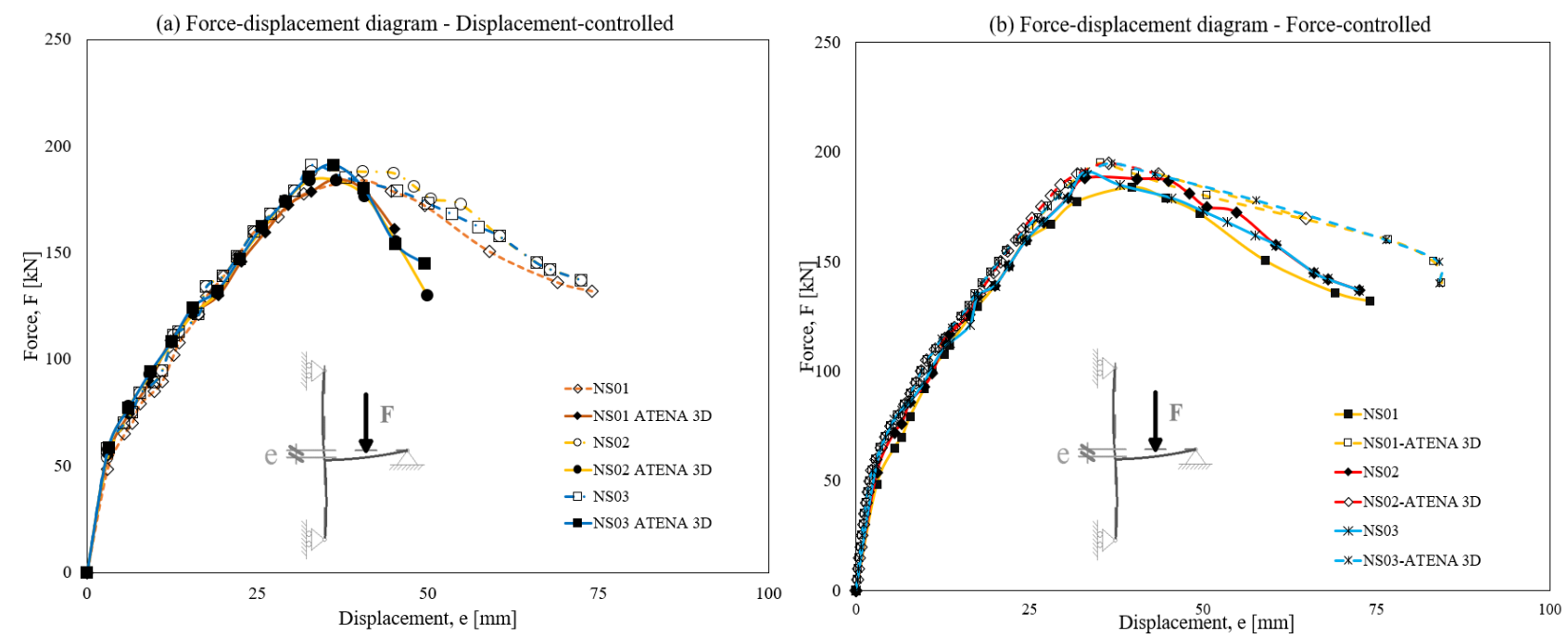

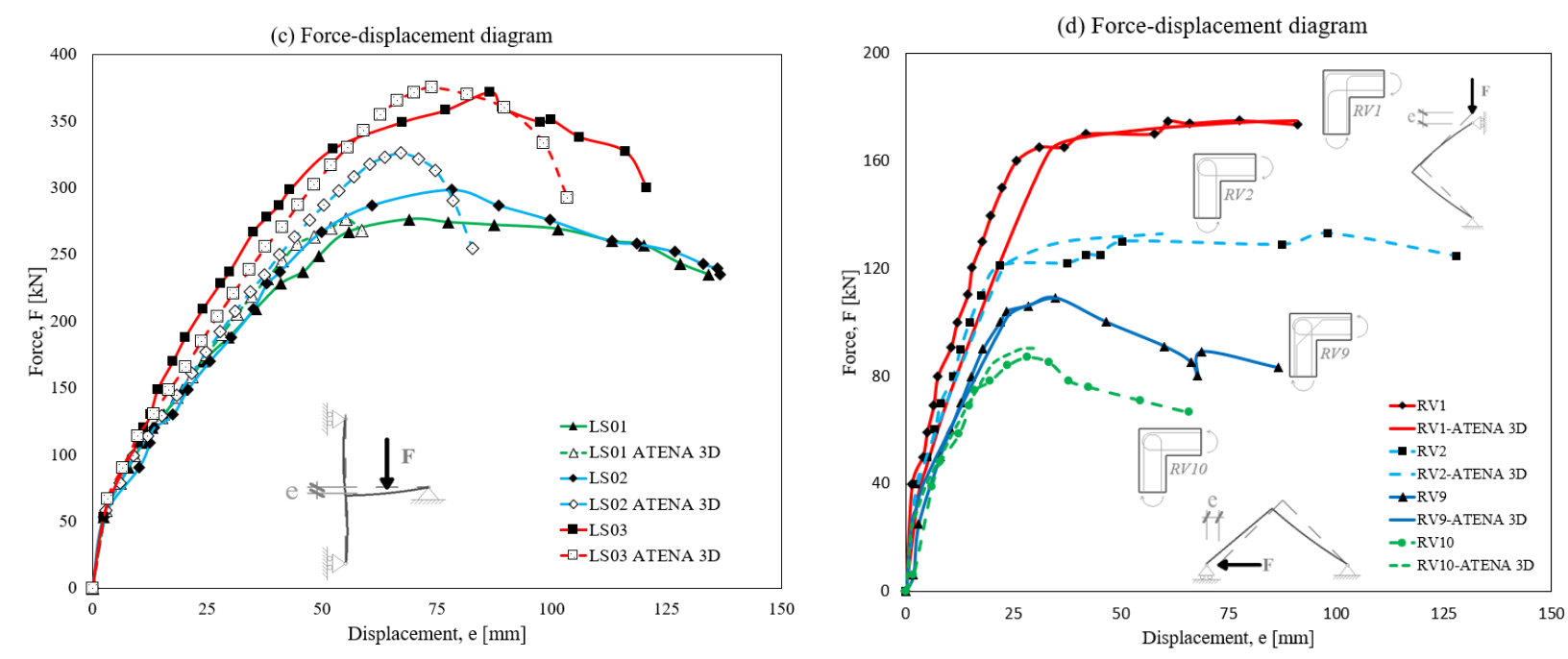

In the following, we summarize and compare the laboratory results (Masi, Santeriero \& Nigro, 2013) found in the literature and the numerical experiment results obtained with cyclic load models. The detailed results of the laboratory experiments were not available; only the force-drift diagrams were presented in the publication, so they are illustrated in separate diagrams transferred from the original publication. The following diagrams compare the results of the experiments performed on specimens "NE RB" (See Figure $9(a, b)$ ). The values of the envelope of the force-drift diagrams obtained in the laboratory experiments are compared with the results of the numerical experiments performed by us.

In the case of specimen "NE RB", the displacement in the first cycle has already cracked the concrete cross-section, so the extreme value of the first cycle already occurs in stress state II. The extreme values of the first load level of the numerical test are almost the same as those of the laboratory experiments (deviation in positive load: $-0.19 \%$; negative load: $+0.59 \%$ ). The results obtained at the second and third load level also show a good match, with $4.99 \%$ in the positive direction and $-2.14 \%$ in the negative direction. We could not continue the numerical experiments after the third load level: the structure was ruined. The force associated with the failure $(16.86 \mathrm{kN})$ of the finite element model and the force determined in the laboratory test $(18.24 \mathrm{kN})$ are nearly the same.

The numerical and experimental results for specimen "Z4 RB" are shown in Figure 9(c, d). At the first load level, the displacement rate in this case was also such that the critical cross-section of the structure was cracked. The force measured by the numerical test was $22.31 \mathrm{kN}$ and $24.38 \mathrm{kN}$ in the laboratory experiment. At the second load level, there is a good match between numerical and laboratory tests in the direction of negative and positive load direction (difference: $+1.24 \%,+9.17 \%$ ). After the third load level, the numerical test stopped in this case, but there is no big difference between the force obtained in the numerical test $(37.11 \mathrm{kN} ;-41.36 \mathrm{kN})$ and the force measured in the laboratory experiment (41.06 kN; -39.87 kN).

Similarly to the above, the force-drift diagrams determined in the numerical and laboratory experiments in specimens "Z2 RB" are shown in Figure 9(e,f). The same behavior as that of specimens "NE RB" and +Z4 RB" is observed. In this case, there is also a good match between numerical and laboratory experiment results at this first load level (difference: $-3.28 \% ;+8.08 \%)$. The results of the second and third load level also show a good match (+9.5\%; $-10.24 \%$; $-2.51 \%$; $3.75 \%)$. At the third load level, the finite element calculation was not continued in this case, and the calculation stopped at a load of $39.60 \mathrm{kN}$ during the test. The results of the numerical and laboratory experiments performed are summarized in Table 6. 
Table 5. Comparison of numerical and experimental results. Source: Self-Elaboration; Sin \& Bing (2011); Morgan (2000).

\begin{tabular}{|c|c|c|c|c|}
\hline Specimen & Type of the experiments & $\begin{array}{l}\text { Cracking } \\
\text { force }[k N]\end{array}$ & $\begin{array}{l}\text { Force at failure } \\
{[\mathrm{kN}]}\end{array}$ & $\begin{array}{l}\text { Displacement at failure } \\
{[\mathrm{mm}]}\end{array}$ \\
\hline \multirow[t]{5}{*}{ NS01 } & Laboratory & 48.50 & 184.00 & 39.80 \\
\hline & Numerical (force-controlled) & 48.00 & 193.00 & 35.40 \\
\hline & Numerical (displacement-controlled) & 49.35 & 193.81 & 36.58 \\
\hline & Difference [\%] (force-controlled) & -1.03 & +4.66 & -11.05 \\
\hline & Difference [\%] (displacement-controlled) & +1.72 & +5.06 & -8.09 \\
\hline \multirow[t]{5}{*}{ NSO2 } & Laboratory & 53.70 & 188.00 & 33.10 \\
\hline & Numerical (force-controlled) & 54.00 & 194.50 & 36.40 \\
\hline & Numerical (displacement-controlled) & 53.45 & 183.81 & 36.58 \\
\hline & Difference [\%] (force-controlled) & +0.55 & 3.34 & +9.06 \\
\hline & Difference [\%] (displacement-controlled) & -0.46 & -2.23 & +9.51 \\
\hline \multirow[t]{5}{*}{ NSO3 } & Laboratory & 57.80 & 191.10 & 33.00 \\
\hline & Numerical (force-controlled) & 57.50 & 195.00 & 36.80 \\
\hline & Numerical (displacement-controlled) & 58.63 & 191.18 & 36.14 \\
\hline & Difference [\%] (force-controlled) & -0.51 & +2.00 & +10.33 \\
\hline & Difference [\%] (displacement-controlled) & +1.41 & +0.04 & +8.68 \\
\hline \multirow[t]{3}{*}{ LS01 } & Laboratory & 57.39 & 276.30 & 69.00 \\
\hline & Numerical (force-controlled) & 53.30 & 276.50 & 55.20 \\
\hline & Difference [\%] (force-controlled) & -7.89 & +0.07 & -20.00 \\
\hline \multirow[t]{3}{*}{ LSO2 } & Laboratory & 57.86 & 298.60 & 78.20 \\
\hline & Numerical (force-controlled) & 53.10 & 326.10 & 67.14 \\
\hline & Difference [\%] (force-controlled) & -8.22 & +8.43 & -14.14 \\
\hline \multirow[t]{3}{*}{ LS03 } & Laboratory & 66.53 & 371.70 & 86.50 \\
\hline & Numerical (force-controlled) & 53.80 & 375.10 & 73.85 \\
\hline & Difference [\%] (force-controlled) & -19.31 & +0.91 & -14.60 \\
\hline \multirow[t]{3}{*}{ RV1 } & Laboratory & 40.00 & 165.00 & 31.00 \\
\hline & Numerical (force-controlled) & 39.10 & 165.54 & 34.52 \\
\hline & Difference [\%] (force-controlled) & -2.25 & +0.33 & +10.19 \\
\hline \multirow[t]{3}{*}{ RV2 } & Laboratory & 38.00 & 121.00 & 22.00 \\
\hline & Numerical (force-controlled) & 35.70 & 122.40 & 39.78 \\
\hline & Difference [\%] (force-controlled) & -6.05 & +1.14 & +44.69 \\
\hline \multirow[t]{3}{*}{ RV9 } & Laboratory & 27.20 & 109.00 & 34.70 \\
\hline & Numerical (force-controlled) & 28.90 & 108.80 & 32.74 \\
\hline & Difference [\%] (force-controlled) & +5.88 & -0.18 & -5.65 \\
\hline \multirow[t]{3}{*}{ RV10 } & Laboratory & 24.20 & 87.00 & 28.30 \\
\hline & Numerical (force-controlled) & 23.80 & 90.10 & 27.13 \\
\hline & Difference [\%] (force-controlled) & -1.65 & +3.44 & -4.13 \\
\hline
\end{tabular}

Figure 9. Comparison of numerical and experimental results. Source: Self-Elaboration; Masi, Santeriero \& Nigro (2013).
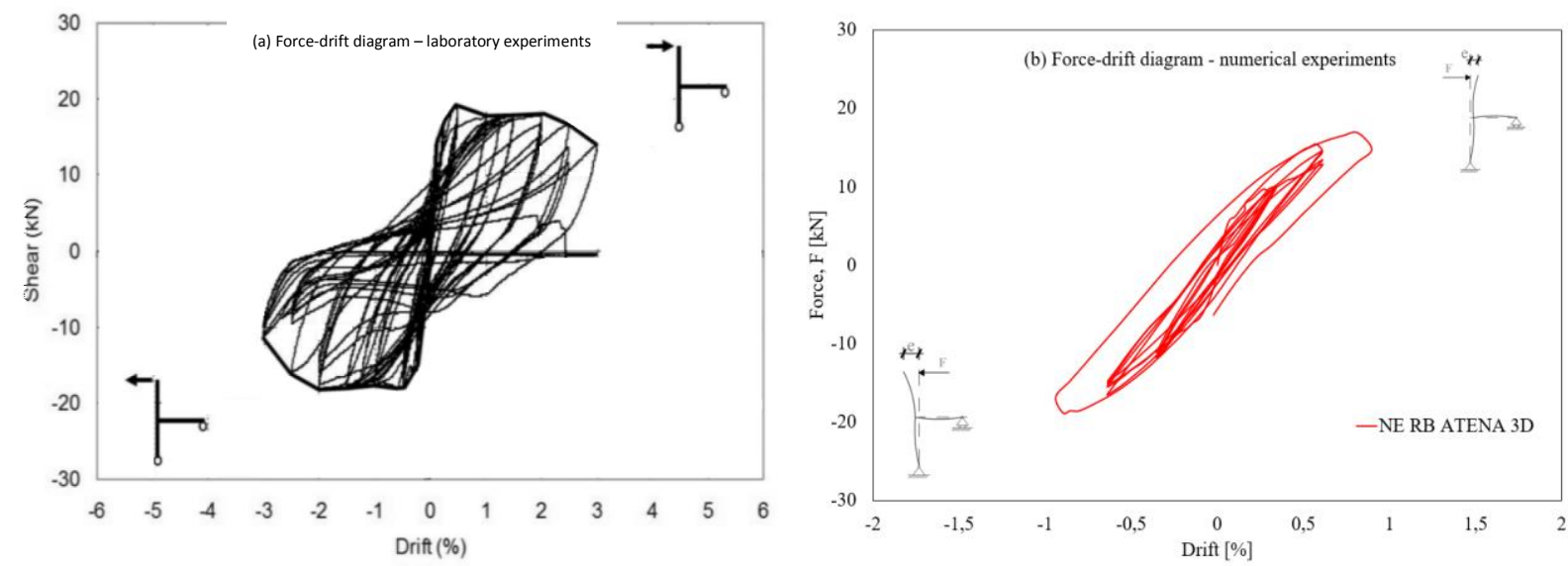

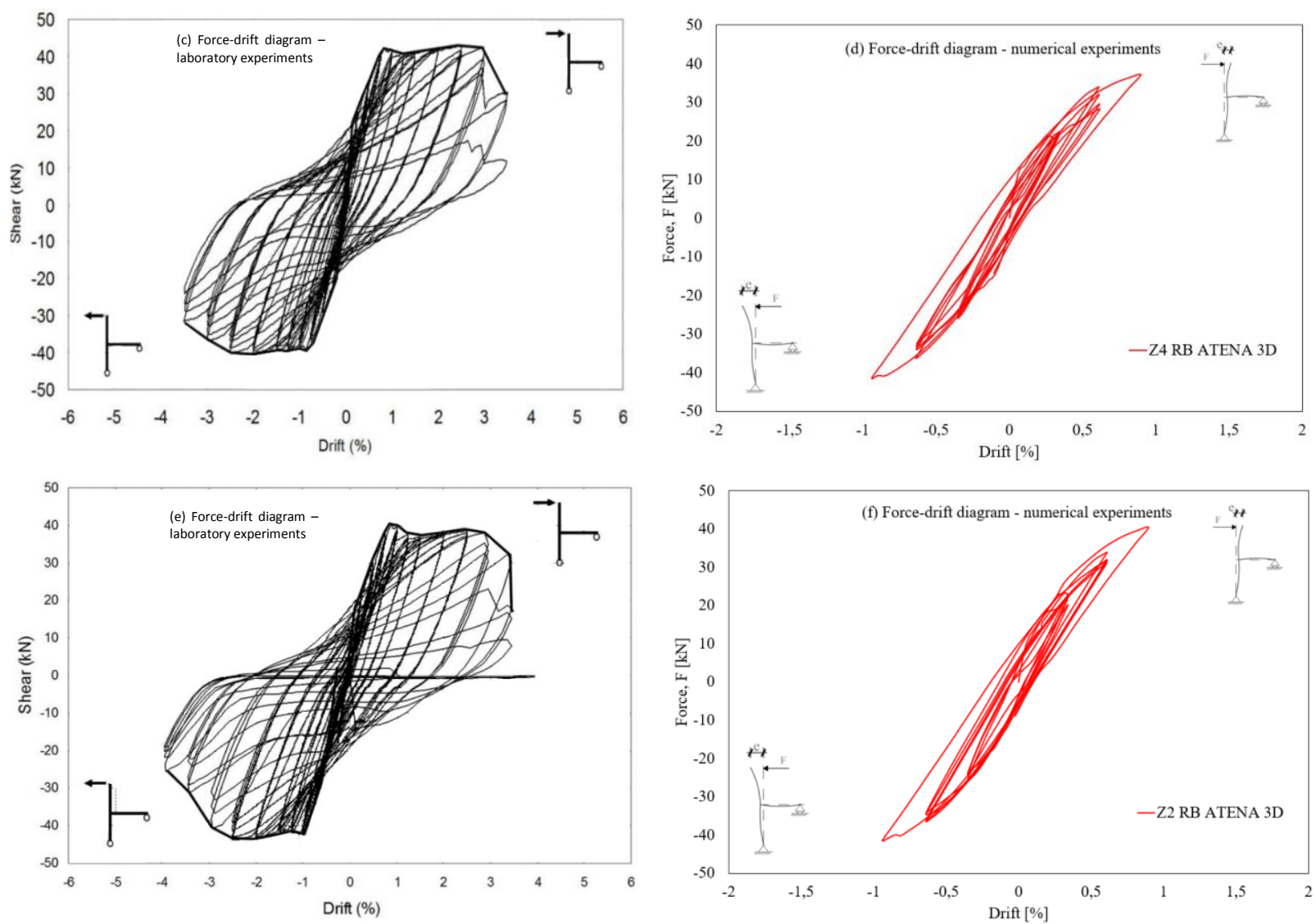

Table 6. Comparison of numerical and experimental results. Source: Self-Elaboration; Masi, Santeriero \& Nigro (2013).

\begin{tabular}{|c|c|c|c|c|c|c|c|c|c|c|}
\hline \multirow[b]{2}{*}{ Specimen } & \multirow{2}{*}{$\begin{array}{c}\text { Direction } \\
\text { of the } \\
\text { load }\end{array}$} & \multicolumn{2}{|c|}{$\begin{array}{c}\text { Force at the 1st load } \\
\text { level }[\mathrm{kN}]\end{array}$} & \multirow{2}{*}{$\begin{array}{c}\text { Difference } \\
{[\%]}\end{array}$} & \multicolumn{2}{|c|}{$\begin{array}{c}\text { Force at the } 2 \text { nd load } \\
\text { level }[\mathrm{kN}]\end{array}$} & \multirow{2}{*}{$\begin{array}{c}\text { Difference } \\
{[\%]}\end{array}$} & \multicolumn{2}{|c|}{$\begin{array}{c}\text { Force at the 3rd load } \\
\text { level }[\mathrm{kN}]\end{array}$} & \multirow{2}{*}{$\begin{array}{c}\text { Difference } \\
{[\%]}\end{array}$} \\
\hline & & Laboratory & Numerical & & Laboratory & Numerical & & Laboratory & Numerical & \\
\hline \multirow{2}{*}{ NE RB } & Positive & 10.16 & 10.14 & -0.19 & 16.22 & 15.41 & -4.99 & 18.24 & 16.86 & -7.56 \\
\hline & Negative & 11.68 & -11.75 & +0.59 & -16.85 & -16.49 & -2.14 & -17.84 & -18.80 & +5.11 \\
\hline \multirow{2}{*}{ Z4 RB } & Positive & 24.38 & 22.31 & -8.49 & 33.48 & 33.90 & +1.24 & 41.06 & 37.11 & -9.62 \\
\hline & Negative & -23.38 & -25.85 & +9.55 & -32.95 & -36.28 & +9.17 & -39.87 & -41.36 & +3.6 \\
\hline \multirow{2}{*}{ Z2 RB } & Positive & 23.71 & 22.93 & -3.28 & 30.05 & 33.22 & +9.54 & 40.62 & 39.60 & -2.51 \\
\hline & Negative & -23.78 & -25.87 & +8.08 & -32.77 & -36.51 & -10.24 & -42.35 & -40.76 & -3.75 \\
\hline
\end{tabular}

\section{Conclusions}

Within the framework of this article, numerical studies of beam-column and frame corner joints were performed under monotonic increasing quasi-static and cyclic load using a 3D modeling method developed by us. The numerical models were constructed with the actual concrete cross-sections and reinforcements used in the laboratory experiments (Sin \& Bing, 2011, Morgan, 2000, Masi, Santeriero \& Nigro, 2013) found in the literature to be directly compared with them. Numerical tests were performed with the ATENA 3D nonlinear finite element program. The results of the numerical studies were presented and compared with the results of the laboratory experiments referred to. Based on the numerical tests we carried out using the modeling method we developed, we make the following statements:

- When testing the beam-column connections, denser stirrup distance for test specimens "NS" does not result in a significant difference in load-bearing capacity. However, the results are very well matched (deviation of the force at failure: 0.04 to $8.43 \%$ ) regarding the numerical tests. In order to properly evaluate the behavior of the relationship, we also recorded the deflection values associated with the failure, which also show a good match compared to experiments performed in the laboratory (difference: 8.09 to $20.00 \%$ ).

- In the case of beam-column specimens "NS" and "LS", between the initial cracking (stress state I) and failure (stress states II and III) a very good match can be found (deviation: force at failure: 4 to $8 \%$ ). In case of specimens "NS" there is no significant difference in the section up to failure. 
- Within displacement-controlled numerical experiments, the assumed plastic deformation phase after failure is not modeled by the modeling technique we used. In force-controlled numerical analyses, on the other hand, it is possible to show the plastic or so-called descending behavioral phase following the failure.

- Large plastic deformations were observed in test specimens "LSO2" and "LSO3", but after failure, numerical calculations were continued. Until failure, the results show a good match (difference: force at failure: $+0.07 \%$, $+8.43 \%,+0.91 \%)$.

- In the case of specimens "RV", a good match can be found between the results obtained by numerical tests and the results of the laboratory experiments (deviation of the force at failure: 0.33 to $1.14 \%$ ).

- It can be stated that numerical models set up with the actual (real) reinforcement characteristics have better results (deviation of displacement: 4 to 11\%) than models where linear elastic - linear hardening reinforcement material models were used (deviation of displacement: 4 to $20 \%$ ). The plastic deformations after failure can be modeled using the real reinforcement characteristics.

- Specimen "NE RB" has a significantly lower load-bearing capacity (almost half) compared to specimens "Z2 RB" and "Z4 RB" with a higher tensile reinforcement and denser stirrup distance.

- It can be observed in the individual numerical studies that the force of the same displacement values shows a decreasing tendency; the friction and degradation of the concrete can be examined by the modeling method we used. At the extreme values of each cycle, the measured force is reduced to between 1 and $16 \%$ in the first cycle (same load level).

- Within the limit of the horizontal displacement determined by us, the numerical results are very close (difference: 2 to $10 \%$ ) to the results of the laboratory experiments.

- In addition to the displacement limit set by us, the finite element calculation cannot be performed using the modeling technique applied. The value given as a barrier is still close to the small displacements; besides, we have to apply a modeling procedure that takes large deformations into account.

- The drift ratio of 1 to $2.5 \%$ above the limit of drift defined by us can be tested with the new, improved modeling technique which we are currently developing.

All in all, with the modeling technique we have defined, the real behavior of cast-in-situ RC beam-column and frame corner joints can be approached numerically under both one-way monotonic increasing and cyclic load. The joints and their different reinforcement designs can be modeled with the modeling method developed by us using threedimensional nonlinear finite element software to accurately describe the behavior. The numerical results obtained are technically acceptable for laboratory experiments (Sin \& Bing, 2011, Morgan, 2000, Masi, Santeriero \& Nigro, 2013) performed in international research programs. With this modeling technique, it is possible to examine the effect of the actual reinforcement design that has a fundamental impact on the complex behavior of structural joints or details. The "efficiency" of the reinforcement applied and the amount of the bars can be quantified and optimized if necessary. We have shown that it is possible to analyze the complex behavior of monolithic RC frame corners with identical reinforcements under one-way monotonic increasing quasi-static loading, instead of a series of very expensive laboratory experiments. In finite element calculations, we applied horizontal cyclic loads and also vertical quasi-static loads, with which we were able to accurately analyze the complex behavior of the tested specimen's joints from a technical point of view. Based on the results obtained, it is possible to examine structures and reinforcement designs not tested in laboratory conditions. With the modeling technique developed, it is also possible to investigate the behavior of new or not even existing RC joints against seismic and cyclic horizontal loads. In addition to the limitations of the drift ratio within the scope of this article, we plan to investigate a new modeling technique that is currently under development.

Modeling techniques can also explore further research opportunities and directions, such as:

- Investigating cast-in-situ RC wall-slab connections for horizontal cyclic load,

- Developing a method for modeling large deformations of RC details,

- Testing the possibilities of the modeling of overlapped reinforcement,

- Examining different modeling options for stirrups,

- Modeling the connections of concrete elements at different construction stages.

References

Beckingsale, Ch. W. (1980). Post Elastic Behavior of Reinforced Concrete Beam-Column Joints, Degree of Doctor of Philosophy in Civil Engineering at the University of Canterbury, Christchurch, New Zealand. Retrieved from https://ir.canterbury.ac.nz/handle/10092/7749

Campana S., Fernández Ruiz M. \& Muttoni A. (2013). Behaviour of nodal regions of reinforced concrete frames subjected to opening moments and proposals for their reinforcement. Engineering Structures, 51, 200-210. 
Cervenka, V. (1985). Constitutive Model for Cracked Reinforced Concrete. Journal ACl, 82(6), 877-882.

Cervenka, V., Jendele, L. \& Cervenka, J. (2014). ATENA Program Documentation Part 1, Theory Cervenka Consulting s.r.o, 19. Retrieved from http://www.technologismiki.com/uplx/ATENA_Theory.pdf

Crisfield, M.A., \& Wills, J. (1989). The Analysis of Reinforced Concrete Panels Using Different Concrete Models. J. Eng. Mech. - ASCE, 115(3), 578-597.

Darwin, D., Pecknold, D.A.W. (1974). Inelastic Model for Cyclic Biaxial Loading of Reinforced Concrete. Civil Engineering Studies, University of Illinois, July. Retrieved from https://www.ideals.illinois.edu/bitstream/handle/2142/13822/SRS-409.pdf?sequence=2

Engindeniz, M., Kahn, L. F. \& Zureick A-H. (2005). Performance of an RC Corner Beam-Column Joint Severely Damaged under Bidirectional Loading and Rehabilitated with FRP Composites. ACl-ASCE Committee SP-258-2. Retrieved from https://books.google.hu/books?hl=hu\&lr=\&id=gl72a6OHeQIC\&oi=fnd\&pg=PA25\&dq=Performance+of+an+RC+Corner+BeamColumn+Joint+Severely+Damaged+under+Bidirectional+Loading+and+Rehabilitated+with+FRP+Composites\&ots=J_xdiLXr6a\&sig=evktdVyLZnH2xX7CQ1XrjspJlo\&redir_esc=y\#v=onepage\&q=Performance\%20of\%20an\%20RC\%20Corner\%20BeamColumn\%20Joint\%20Severely\%20Damaged\%20under\%20Bidirectional\%20Loading\%20and\%20Rehabilitated\%20with\%20FRP\%20Composites\& $\mathrm{f}=$ false

CEB-FIP Model Code 1990 (1993). Redwood Books, Trowbridge, Wiltshire, Retrieved from https://books.google.hu/books?id=IRG9GTPJ7s8C\&printsec=frontcover\&source=gbs_ge_summary_r\&cad=0\#v=onepage\&q\&f=false

fib Model Code for Concrete Structures, 2010, (2013). Wilhelm Ernst \& Sohn, Berlin, Retrieved from https://doi.org/10.1002/9783433604090

Haris, I. \& Roszevák, Zs. (2017). Előregyártott vasbeton gerendák numerikus és kísérleti vizsgálata. Vasbetonépítés: A FIB magyar tagozat lapja: Müszaki folyóirat, 19(1), 2-11.

Hawileh, R.A., Rahman, A., \& Tabatabai, H. (2010). Nonlinear finite element analysis and modeling of a precast hybrid beam-column connection subjected to cyclic loads. Applied Mathematical Modelling, 34(9), 2562-2583.

Hordijk, D.A. (1991). Local Approach to Fatigue of Concrete. (Doctor dissertation), Delft University of Technology. The Netherlands, ISBN 90/90045198.

Himanshu, G. \& Roashan, L. (2018). Analytical Investigation on Behaviour of RC Framed Corner Joints. International Journal of Advance Engineering and Research Development (IJAERD), 5(2), 2348-4470.

Hwang, S-J. \& Lee, H-J. (1999). Analytical Model for Predicting Shear Strength of Exterior Reinforced Concrete Beam-Column Joints for Seismic Resistance. ACl Journal, 96(5).

Kazinczy, G. (1917). Kísérletek vasbeton medence-sarokkal, Magyar Mérnök és Építészegylet Közlöny, 51(9), 78-83.

Kolmar, W., (1986). Beschreibung der Kraftuebertragung über Risse in nichtlinearen Finite-Element-Berechnungen von Stahlbetontragwerken. Dissertation, T.H. Darmstadt, p. 94.

Kordina, K. \& Kohler, G. (1971). Tragverhalten der Stützenschlüsse in Rahmenknoten bei herabgesetzter Verankerungs/änge der Anschlußbewehrung, 1. Zwischenbericht. Lehrstuhl für Stahlbeton- und Massivbau, Institut für Baustoffkunde und Stahlbetonbau, Technische Universität Braunschweig. Retrieved from https://publikationsserver.tu-braunschweig.de/servlets/MCRFileNodeServlet/dbbs_derivate_00035108/300192-001-Kordina.pdf

Kordina, K. (1978). Tragverhalten von Rahmenknoten bei herabgesetzter Verankerungslänge der Anschlußbewehrung unter Berücksichtung der Bewehrungsführung. Lehrstuhl für Stahlbeton- und Massivbau, Institut für Baustoffkunde und Stahlbetonbau, Technische Universität Braunschweig. Retrieved from https://publikationsserver.tu-braunschweig.de/servlets/MCRFileNodeServlet/dbbs_derivate_00035108/300192-001-Kordina.pdf

Korina, K., Teutsch, M. \& Wegener, E. (1995). Trag- und Verformungsverhalten von Rahmenknoten. Schlußbericht, Deutschen Forschungsgemeinschaft, Kennziffer, 201(37). Retrieved https://publikationsserver.tubraunschweig.de/servlets/MCRFileNodeServlet/dbbs_derivate_00036139/30-0400-001-Kordina.pdf

Kupfer, H., Hilsdorf, H.K., \& Rüsch, H. (1969). Behavior of Concrete under Biaxial Stress, Journal ACl, 66(8), 656-666.

Lowes, L.N., Mitra, N. \& Altoontash, A. (2003). A Beam-Column Joint Model for Simulating the Earthquake Response of Reinforced Concrete Frames. Pacific Earthquake Engineering Research Center, University of California, Berkeley, August 2003.

Megget, L. M., Fenwick, R. C. \& Amso, N. (2003). Seismic performance of internal beam-column joints with 500 grade reinforcement. 2003 Pacific Conference on Earthquake Engineering. pp. 100

Morgan J. (2000). Structural Behavior in Concrete Frame Corners of Civil Defense Shelters. Thesis for the degree of doctor of philosophy, Division of Concrete Structures, Department of Structural Engineering, Chalmers University of Technology, Göterborg, Sweden.

Park, R. \& Thompson, K. J. (1977). Cyclic Load Tests on Prestressed and Partially Prestressed Beam-Column Joints. PCI Journal, 22(5) pp84-110.

Park, R. \& Keong, Y. S. (1979). Tests on Structural Concrete Beam-Column Joints with Intermediate Column Bars, Bulletin of New Zealand Society for Earthquake Engineering, 12(3).

Pessiki, S. P., Conley, C. H., Gergely, P. \& White, R. N. (1990). Seismic Behavior of Lightly-Reinforced Concrete Column and Beam-Column Joints Details, Technical Report NCEER-90-0014, August 22, 1990.

Roszevák, Zs. \& Haris, I. (2017). Comparison of different models on different cast-in-situ RC joints. 12 ${ }^{\text {th }}$ Central European Congress on Concrete Engineering 2017 Tokaj. pp. 648-658.

Sahriar, S. \& Hunar, F. H. A. (2019). Numerical simulation of shear-strengthening of reinforced concrete beams by CFRP under cyclic loading. Revista de la Construcción, 18(2), 271-281. 
Szczecina, M. \& Winnicki, A. (2015). Numerical simulations of corners in RC frames using strut-and-tie method and CDP model. XIII International Conference on Computational Plasticity, Fundamentals and Applications COMLPAS XIII.

Van Mier, J.G.M. (1986). Multi-axial Strain-softening of Concrete, Part I: fracture. Materials and Structures, RILEM, 19(111).

Vecchio, F.J., \& Collins, M.P. (1986). Modified Compression-Field Theory for Reinforced Concrete Beams Subjected to Shear. ACl Journal, 83(2), 219231.

Windisch, A. (2018). Egységes méretezési modell, Vasbetonépítés: A FIB magyar tagozat lapja. Müszaki folyóirat, 20(1), 2-9.

Yap, S. L., and Li, B. (2011). Experimental investigation of reinforced concrete exterior beam-column sub assemblages for progressive collapse, ACI Structural. 108(5), 542-552. 